\title{
Improving the Extraction Process of Sodium Alginate from Samu (Sargassum piluliferum) using the Plackett- Burman Design
}

Ma. Aezel M. Aguanza ${ }^{1 \star}$, Roberta B. Lauzon ${ }^{2}$ and Ivy C. Emnace ${ }^{3}$

\section{ABSTRACT}

Alginates, which are mainly produced from kelp, improve and stabilize the texture of foods. Thus, they are important in the food and beverage industry. Brown seaweeds such as Sargassum piluliferum are abundant in the Philippines and could be potential sources of alginates. The PlackettBurman screening was used as a tool to evaluate the importance of seven selected variables (formaldehyde solution, extractant ratio, $\mathrm{Na}_{2} \mathrm{CO}_{3}$ concentration, $\mathrm{HCl}$ concentration, extraction temperature, bleaching, and precipitant), which influence the extraction process of sodium alginates. The main factors that affected the extraction of sodium alginates were extraction ratio, $\mathrm{Na}_{2} \mathrm{CO}_{3}$ concentration, and bleaching. Extraction ratio and $\mathrm{Na}_{2} \mathrm{CO}_{3}$ significantly affected the production of sodium alginate by lowering the level of extractant concentration and obtaining a positive effect in terms of its yield. Bleaching with $\mathrm{NaOCl}$ did not significantly affect the yield. However, it had a positive effect on the purity of the alginate which is an essential physico-chemical parameter that reflects the proportion of the target compound. These factors could be further optimized to extract high yield and good quality sodium alginate from Sargassum piluliferum.

Keywords: extractant ratio, Plackett-Burman, Sargassum piluliferum, sodium alginate, sodium carbonate, sodium hypochlorite

\section{INTRODUCTION}

Macro algae are interesting sources of different bioactive polysaccharides, the uses of which range from industrial to novel food applications. These possess many different and often exotic polysaccharides that are currently explored for their functional properties in food and biomedicine (Kraan 2012). Alginates are the most abundant polysaccharides present in brown seaweeds (Fernandez et al 2009). There

\footnotetext{
${ }^{1}$ Bohol Island State University-Calape Campus, Calape, Bohol, Philippines

${ }^{2,3}$ Visayas State University, Department of Food Science and Technology, Visca, Baybay City, Leyte, Philippines 
are specific tropical seaweeds that are potential sources of alginates. Sargassum, a brown alga, appears to be the most promising. It is usually the most ecologically dominant species along tropical and subtropical coasts (Prince et al 1979) and plays a remarkable economic role as a source of alginates (Blanshard \& Mitchell 2013). It is one of the commonly found brown macro algae in the Philippines, with 72 recorded species (Ortis \& Tromo 2000). The abundance of these species in the country is an opportunity to improve their marketing form into more expensive and value added products. One of the ways to do this is to extract their important polysaccharides, specifically alginates.

Alginates are used as organoleptic additives and stabilizers to improve, modify, and stabilize the texture of food (Nalamothu et al 2014). The extraction process should use suitable methods to obtain high yield and good quality alginates. This can influence the yield and chemical composition as well as rheological properties of the isolated alginates (McHugh 2003, Hernandez-Carmona, Freile-Pelegrin \& Hernandez-Garibay 2013; Gomez et al 2009 as cited in Peteiro 2018).

In order to determine the effect of numerous factors affecting the alginate extraction process, a screening design should be performed. According to Vanaja and Shobha (2008), a 'screening design' refers to an experimental design which can be applied when a large number of potential causative factors have to be examined, to identify the most important ones that may have an effect on one or more responses of interest. This will reduce the number of factors to be investigated in further experimentation. When there are many factors to be tested, the Plackett-Burman design is an excellent option, since it allows the understanding of the effects of various physico-chemical, biochemical, and sensory variables using a minimum number of experiments. Plackett-Burman is a design widely used in food research because it allows the screening of the main factors from a large number of variables that can be retained in the further optimization process (Siala et al 2012). The projective property of the Plackett-Burman design is that it allows the experimenter to follow up an initial design with runs that allow an efficent separation of main effects and interactions (Wass 1997; Nijhuis et al 1999; Plackett \& Burman 1946; Yannis 2001 as cited in Siala et al 2012).

Hence, this study explored the possibility of expanding the use of Sargassum, which is largely underused despite its abundance, to a more profitable value added form through the production of sodium alginate. Generally, this study aimed to extract and use sodium alginate from locally found Sargassum piluliferum; identify the effects of the different variables that influence the extraction of sodium alginate using Plackett-Burman design; and evaluate the physical and chemical characteristics (moisture content, ash content, $\mathrm{pH}$, alginate purity, and percent yield) of the extracted sodium alginate. 


\section{MATERIALS AND METHODS}

\section{Procurement of Materials}

The Sargassum piluliferum was procured from Higatangan Island, Biliran. The chemicals and reagents used were purchased from Far Eastern Drug and Yana Commodities in Cebu City, Philippines.

\section{Preparation of Sargassum piluliferum}

The Sargassum piluliferum underwent different preparation methods based on the defined variables used. Sargassum was dried in a cabinet drier for $8-10$ hours at $60^{\circ} \mathrm{C}$. Then it was milled to powder using a grinder. The powdered Sargassum was kept in a clean container, ready for use.

\section{Extraction Process of Sodium Alginate}

The extraction of sodium alginate was done using different methods based on the concentration and temperature of extractants and conditions used. The Sargassum was soaked for 24 hours in $0.1 \%$ (Reyes et al 2005) and $0 \%$ formaldehyde solution and washed with distilled water. The leaching process was done by soaking Sargassum in $0.5 \mathrm{~N} \mathrm{HCl}$ (Kasim et al 2017) and $0.3 \mathrm{~N} \mathrm{HCl}$ for 2 hours. Afterwards, it was washed with distilled water until the $\mathrm{pH}$ was neutral. It was then bleached using $100 \mathrm{~mL} 5 \%$ hypochlorite $(\mathrm{NaOCl})$ for 30 minutes and washed with distilled water. It was extracted by heating with $7.5 \%$ (Zailanie 2015) and 3\% (Mazumder et al 2014) sodium carbonate $\left(\mathrm{Na}_{2} \mathrm{CO}_{3}\right)$ for 3 hours at a temperature of $90^{\circ} \mathrm{C}$ (Mazumder et al 2014) and $60^{\circ} \mathrm{C}$ (Mushollaeni 2011). Then, it was filtered with a fine mesh cloth and the filtrate was collected. The filtrate was washed three times with distilled water. It was slowly added with $10 \% \mathrm{HCl}$ while stirring until $\mathrm{pH} 2$ was attained. Alginic acid, characterized by the deposition in the form of gel, was obtained (Kasim et al 2017). The precipitated alginic acid was then collected and washed with distilled water. The alginic acid was added with $10 \%$ sodium carbonate $\left(\mathrm{Na}_{2} \mathrm{CO}_{3}\right)$ (Mushollaeni 2011) and stirred until its $\mathrm{pH}$ reached less than 8 (Reyes et al 2005) and finally precipitated with 95\% isopropanol (Zailanie 2015) and $94 \%$ ethanol (Mazumder et al 2014) to obtain a fiber sodium alginate. The sodium alginate precipitate was then filtered and dried in an oven at a temperature of $45^{\circ} \mathrm{C}$ for 15 hours. Figure 1 shows the process flow diagram in extracting sodium alginate. 
Improving the Extraction Process of Sodium Alginate from Samu

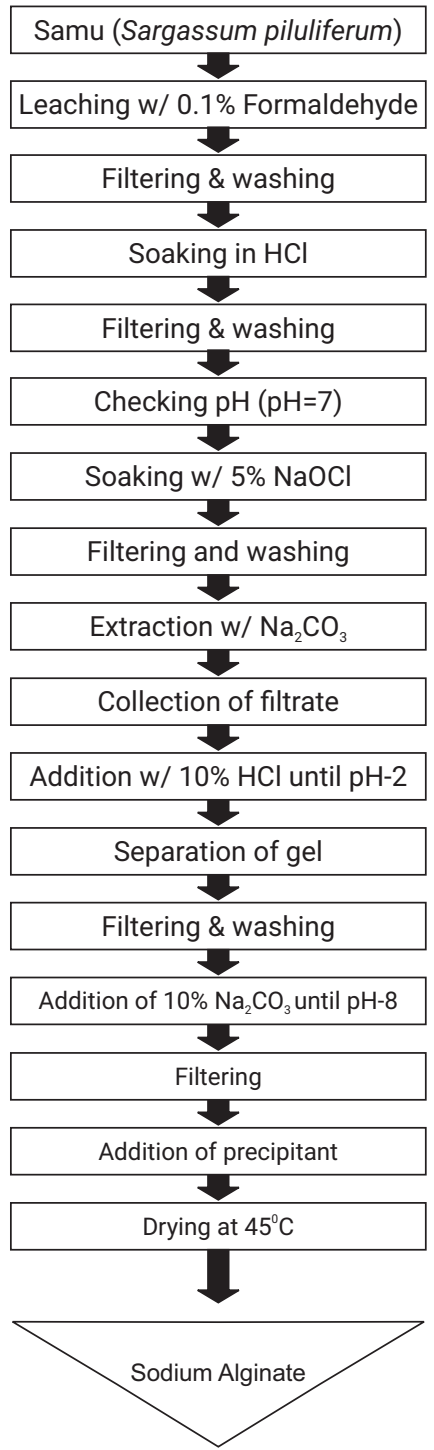

Figure 1. Process flow diagram of sodium alginate extraction

\section{Experimental Design for Screening}

The screening experiment used Plackett-Burman design to identify the most important factors that affected the sodium alginate extraction. Table 1 shows the design set-up for 7 variables having 8 runs, and Table 2 shows the 7 variables-8 runs used in the experiment. 
Table 1. Plackett-Burman Design for 7 variables using 8 runs

\begin{tabular}{cccccccc}
\hline Run & A & B & C & D & E & F & G \\
\hline 1 & + & + & + & - & + & - & - \\
2 & + & + & - & + & - & - & + \\
3 & + & - & + & - & - & + & + \\
4 & - & + & - & - & + & + & + \\
5 & + & - & - & + & + & + & - \\
6 & - & - & + & + & + & - & + \\
7 & - & + & + & - & - & + & - \\
8 & - & - & - & - & - & - & - \\
\hline
\end{tabular}

Table 2. Plackett-Burman 8-run design with 7 variables at high and low values used in the extraction of sodium alginate from Samu (Sargassum piluliferum)

\begin{tabular}{cccccll}
\hline $\begin{array}{c}\text { Extractant } \\
\text { Ratio }\end{array}$ & $\begin{array}{c}\text { Formaldehyde } \\
\text { Concentration } \\
(\%)\end{array}$ & $\begin{array}{c}\mathrm{HCl} \text { Conc. } \\
(\mathrm{N})\end{array}$ & $\begin{array}{c}\mathrm{NA}_{2} \mathrm{CO}_{3} \\
\mathrm{Conc} . \\
(\%)\end{array}$ & $\begin{array}{c}\mathrm{NA}_{2} \mathrm{CO}_{3} \\
\mathrm{Temp} \\
\left({ }^{0} \mathrm{C}\right)\end{array}$ & $\begin{array}{l}\text { NaOCl} \\
\text { concentration }\end{array}$ & Precipitant \\
\hline $40: 1$ & 0.1 & 0.5 & 7.5 & 60 & unbleached & $94 \%$ ethanol \\
$40: 1$ & 0.1 & 0.3 & 3 & 60 & bleached & $95 \%$ isopropanol \\
$40: 1$ & 0 & 0.5 & 3 & 90 & unbleached & $95 \%$ isopropanol \\
$20: 1$ & 0.1 & 0.3 & 7.5 & 90 & unbleached & $95 \%$ i sopropanol \\
$40: 1$ & 0 & 0.3 & 7.5 & 90 & bleached & $94 \%$ ethanol \\
$20: 1$ & 0 & 0.5 & 7.5 & 60 & bleached & $95 \%$ i sopropanol \\
$20: 1$ & 0.1 & 0.5 & 3 & 90 & bleached & $94 \%$ ethanol \\
$20: 1$ & 0 & 0.3 & 3 & 60 & unbleached & $94 \%$ ethanol \\
\hline
\end{tabular}

\section{Physico-Chemical Analysis}

\section{Moisture Content}

The empty crucible (plain) with cover was first dried in an oven set at $105^{\circ} \mathrm{C}$ for 3 hours, then transferred to a desiccator for cooling. Afterwards, its weight was taken. This was repeated until a constant weight of the crucibles was obtained. About $3 \mathrm{~g}$ of the sodium alginate sample was weighed on a dish. Then, this was placed in an oven to dry for 3 hours at $105^{\circ} \mathrm{C}$. After drying, the crucible, partially covered with a lid, was placed in the desiccator for cooling. Its weight was taken and the moisture content was determined using the equation below:

Moisture $=\frac{\mathrm{W}_{1}-\mathrm{W}_{2}}{\mathrm{~W}_{1}} \times 100$

where:

$\mathrm{W} 1=$ weight $(\mathrm{g})$ of the sample before drying

W2 = weight $(\mathrm{g})$ of sample after drying 
The method used by Gholamipoor et al (2013) was followed in determining the ash content of the extracted sodium alginate. Five grams of sodium alginate sample was placed in a crucible and dried in an oven at $105^{\circ} \mathrm{C}$ for 30 minutes. The dried sample was weighed again and then calcined in the furnace at $450^{\circ} \mathrm{C}$ for 3 hours. Calcined samples were cooled in a desiccator, and then weighed. The ash content was determined using the equation below:

$$
\text { Ash content }(\%)=\frac{\text { Weight of the ash }}{\text { Weight of the dry algae }} \times 100
$$

\section{pHMeasurement}

The $\mathrm{pH}$ measurement of the alginate was done by dissolving $0.5 \mathrm{~g}$ of sodium alginate in $50 \mathrm{~mL}$ distilled water and heated at $60-70^{\circ} \mathrm{C}$ for 20 minutes while stirring occasionally to make the solution uniform. This was allowed to cool. The $\mathrm{pH}$ of the alginate solution was measured using a HANNA digital portable $\mathrm{pH}$ meter $\mathrm{HI} 98108$.

\section{Alginate Purity Determination}

The method of Hernandez-Carmona et al (1999) as cited by ReyesTesnado et al (2005) was adopted in determining the purity of the alginate produced. One gram of calcium chloride was dissolved in $100 \mathrm{~mL}$ of methanol-water solution (40-60\%). The resulting solution was added to 100 $\mathrm{mL}$ of $0.5 \%$ alginate solution, while gently stirring. Then the precipitate was removed using a fine filter and then washed with $20-80 \%$ methanol-water solution. Second washing was done using $40-60 \%$ methanol-water solution. The precipitated alginate was dried in an oven set at $105^{\circ} \mathrm{C}$ for 2 hours. Then, the alginate was maintained in a desiccator for one hour and weighed. The alginate purity was computed using the formula:

$$
\text { Alginate purity }=\frac{\text { Weight of the precipitate }}{\text { Weight of the initial alginate on dry basis }} \times 100
$$

\section{Percent Yield}

The yield of the extracted sodium alginate was computed using the formula:

$$
\text { Yield of sodium alginate }(\%)=\frac{\text { Weight of sodium alginate }}{\text { Weight of milled seaweed }} \times 100
$$




\section{Statistical Analysis}

The result of the physico-chemical tests from the Plackett-Burman design was analyzed using Statistica 8.0 software to determine the variables which significantly affected the sodium alginate extraction process.

\section{RESULTS AND DISCUSSION}

\section{Variable Screening}

The results of the variable screening showed the effect of the seven variables on yield, moisture content, ash content, $\mathrm{pH}$, and purity of the extracted sodium alginate. Results indicated that the variables having the most number of significant effects were extractant ratio and $\mathrm{Na}_{2} \mathrm{CO}_{3}$ concentration. The variables with the least number of significant results were formaldehyde solution, $\mathrm{HCl}$ concentration, extraction temperature, bleaching, and precipitant (Table 3).

Table 3. Summary of the effects of different parameters on the extraction of sodium alginate using Plackett-Burman design

\begin{tabular}{|c|c|c|c|c|c|}
\hline \multirow[b]{2}{*}{ Parameter } & \multicolumn{4}{|c|}{ Parameters } & \multirow[b]{2}{*}{$\begin{array}{c}\text { Purity } \\
\text { (\%) }\end{array}$} \\
\hline & Yield (\%) & $\mathrm{pH}$ & $\begin{array}{c}\text { Moisture Content } \\
(\%)\end{array}$ & Ash Content (\%) & \\
\hline Mean/Interc. & 17.23 & 10.26 & 15.90 & 67.18 & 81.80 \\
\hline Extractant Ratio & $13.77^{\star \star}$ & $0.08^{\text {ns }}$ & $-8.02^{* *}$ & $-24.98^{* *}$ & $5.04^{* *}$ \\
\hline Formaldehyde & $-1.82^{\text {ns }}$ & - & $-4.69^{* *}$ & $-4.94^{\text {** }}$ & $-0.10^{\mathrm{ns}}$ \\
\hline Sol. & & $0.08^{\mathrm{ns}}$ & & & \\
\hline $\mathrm{HCl}$ Conc. & $0.43^{\mathrm{ns}}$ & $-0.41^{*}$ & $-4.83^{\text {** }}$ & $34.20^{* *}$ & $0.32^{\mathrm{ns}}$ \\
\hline $\mathrm{Na}_{2} \mathrm{CO}_{3}$ Conc. & $-10.62^{\text {* }}$ & $0.01^{\text {ns }}$ & $-5.54^{* *}$ & $-4.91^{* *}$ & $-7.41^{* \star}$ \\
\hline Extraction Temp. & $0.05^{\text {ns }}$ & $0.23^{\text {ns }}$ & $-4.79^{* *}$ & $-26.51^{\text {** }}$ & $2.10^{\mathrm{ns}}$ \\
\hline Bleaching & $3.56^{\mathrm{ns}}$ & $0.11^{\mathrm{ns}}$ & $-2.82^{*}$ & $-2.58^{* \star}$ & 17.61 * \\
\hline Precipitant & $8.32^{* \star}$ & $0.38^{\mathrm{ns}}$ & $-3.19^{*}$ & $-25.89^{\text {** }}$ & $-3.70^{\mathrm{ns}}$ \\
\hline
\end{tabular}

${ }^{n s}$ not significant $(p=0.05){ }^{*}$ significant $(p \leq 0.05){ }^{*}$ significant $(p \leq 0.01)$

\section{Effect of Formaldehyde, $\mathrm{HCl}$, and $\mathrm{NaOCl}$}

Formaldehyde concentration, $\mathrm{HCl}$ concentration, and bleaching with $\mathrm{NaOCl}$ were the pre-extraction parameters used in the variable screening. The method used in extracting sodium alginate from Sargassum piluliferum resulted in solid, fibrous (unmilled), brown alginates (Figure 2). In a similar study conducted by Indrani and Budianto (2013), alginate powder produced by $S$. crassifolium was dark brown, which was probably a reflection of fucoxanthin pigment often contained in certain algae that probably covered 
the other pigments. This is in contrast with the commercially available alginate, in which color treatment or bleaching was done to produce white alginates. Though bleaching was applied in the study as pre-treatment to the milled seaweeds, the percentage of the bleaching agent $(\mathrm{NaOCl})$ used was not enough to produce a white end product. Bleaching with $\mathrm{NaOCl}$ does not significantly affect the yield because its primary purpose is to produce a white end product. However, it has a positive effect on the product's purity (Table 3) which is an essential physico-chemical parameter that reflects the proportion of the target compound. Results of the statistical analysis showed that the influence of $\mathrm{HCl}$ on the yield was at the maximum level, hence, pre-soaking with $\mathrm{HCl}$ was held constant at maximum level. $\mathrm{HCl}$ breaks down the cell walls of seaweed which will facilitate the dissolution of the cell wall to facilitate the extraction (Winarno 1990 as cited by Zailanie 2015). Pre-soaking in $\mathrm{HCl}$ solution hydrolyzed the alginofit cell walls, reduced impurities, and made the alginate easier to extract (Mushollaeni 2007; Truss et al 2001). Hence, bleaching with $\mathrm{NaOCl}$ was the variable considered for optimization.

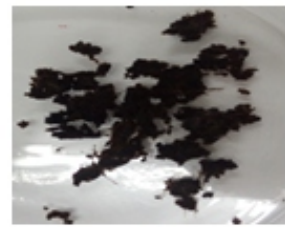

T1

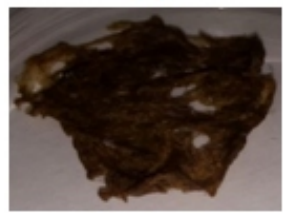

T5

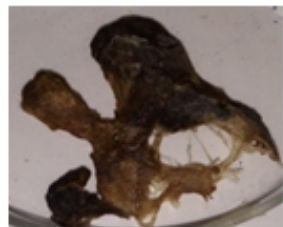

T2

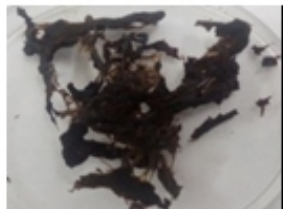

T6

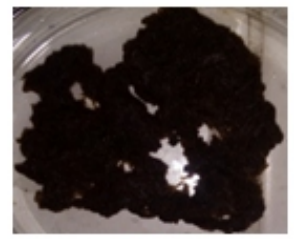

T3

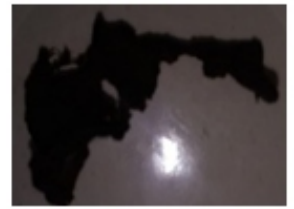

T7

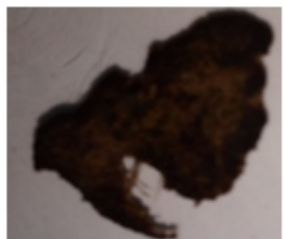

T4

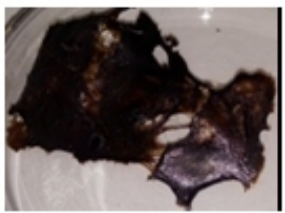

T8

Figure 2. Samples of sodium alginate from each run in Plackett-Burman

Effect of $\mathrm{Na}_{2} \mathrm{CO}_{3}$ Concentration, Extractant Ratio, Temperature and Precipitant

Statistical analysis results showed that the variables, namely: $\mathrm{Na}_{2} \mathrm{CO}_{3}$ concentration, extractant ratio, temperature, and precipitant, greatly affected the alginates' moisture and ash content. All the treatments conformed to the standard moisture value of alginate which is $<15 \%$ (Food and Chemical Codex 1993). On the other hand, the variability in the ash or mineral content of the alginates was due to the different treatments and purification process used (Jayasinghe et al 2016).

In this study, the effect of sodium carbonate concentration and extractant ratio significantly affected the yield of the sodium alginate. It was evident that a lower level of extractant concentration produced a positive 
effect in terms of its yield. This result is supported by the study of Chou and Chiang (1976) as cited by Haerunnisa (2008) which suggested that high concentrations of $\mathrm{Na}_{2} \mathrm{CO}_{3}(3 \%$ to $5 \%)$ reduced yield and viscosity of sodium alginates because the polymer chains of alginic acid degrades into oligosaccharides. In addition, pectin, the adhesive material between the cell walls of brown seaweed, is unstable in alkali solution; it creates a network in the cells of Sargassum sp. to facilitate alginate release. Therefore, $\mathrm{Na}_{2} \mathrm{CO}_{3}$ is a specific solvent to extract alginates from brown seaweed. The maximum level of extractant ratio was also set for optimization since it significantly affected the yield of extracted alginates. Therefore, extractant ratio, $\mathrm{Na}_{2} \mathrm{CO}_{3}$ concentration, and \% $\mathrm{NaOCl}$ were the three variables considered in determining the optimum condition in producing sodium alginate.

Results showed that the extraction temperature had no significant effect on the yield of the alginates. It was evident that at high temperature, the yield increases. Mohamed (2017) states that high temperature increases the yield of extraction. However, high temperature can also lead to the breakdown of uronic acid chains, and, consequently, lower the viscosity of the extracted sodium alginate (Swee-Yong et al 2009). Hence, a temperature of $60^{\circ} \mathrm{C}$ was held for optimization. Statistically, $95 \%$ isopropanol showed a positive effect in terms of yield, which is in accordance with the study conducted by Mairamo (1977), Yunizal et al (1999), and Yani (1998) as cited by Mushollaeni (2011) in which a 75 to $95 \%$ concentration of isopropanol was the finest concentration to get a higher yield of sodium alginate. Moreover, Mushollaeni (2011) states that the use of $95 \%$ isopropanol could increase the yield because of its ability to bind water in the alginate solution so that sodium alginate could be separated. Hence, for optimization, 95\% isopropanol was used as precipitant.

Results showed that the alginate extraction process can influence the yield and chemical composition as well as rheological properties of the isolated alginates (McHugh 2003; Hernandez-Carmona G et al 2013; Gomez et al 2009). Thus, optimization of the process is necessary to maximize the extraction of sodium alginates from Sargassum piluliferum.

\section{CONCLUSION AND RECOMMENDATIONS}

The variable screening Plackett-Burman was used to identify the variables that significantly affected sodium alginate extraction. A 7variable, 8-run screening experiment was conducted with the following variables: formaldehyde solution, extraction ratio, $\mathrm{Na}_{2} \mathrm{CO}_{3}$ concentration, $\mathrm{HCl}$ concentration, extraction temperature, bleaching, and precipitant. The mean results of the physicochemical analysis, namely: yield with $17.23 \%$, $10.2 \mathrm{pH}$ value, moisture content of $15.90 \%$, ash of $67.18 \%$ ash content, and purity of $81.80 \%$ were significantly influenced by the extraction ratio, 
$\mathrm{Na}_{2} \mathrm{CO}_{3}$ concentration and $\mathrm{NaOCl}$ concentration as important factors in sodium alginate extraction. To produce sodium alginate with highest quality and yield, these factors should be optimized. Values for $\mathrm{Na}_{2} \mathrm{CO}_{3}$ concentration at low level and at high level extractant ratio showed a positive effect, whereas $\mathrm{NaOCl}$ showed a negative effect on yield, $\mathrm{pH}$, moisture, and ash content, but showed a positive effect on purity at maximum level.

Optimization of extractant ratio, $\mathrm{Na}_{2} \mathrm{CO}_{3}$ concentration, and $\mathrm{NaOCl}$ concentration is suggested to produce the best quality sodium alginate from Sargassum piluliferum.

\section{REFERENCES}

Blanshard JMV and Mitchell J. 2013. Polysaccharides in Food. Elsevier.

Chou HN and Chiang YM. 1976. Studies on Algin from Brown Algae of

Taiwan. I. Estimation of Yield and quality of Algin. Acta Oceanographica Taiwanica, No. 6. 134-13.

FCC. 1993. Food Chemical Codex. 434: National Academy Press Washington, .

Fernandez-Martin F, Lopez-Lopez I, Cofrades S \& Jimenez Colmenero F. 2009. Influence of adding sea spaghetti seaweed and replacing the animal fat with olive oil or a kinjac gel on pork meat gelatin batter gelation. Potential protein/alginate association. Meat Science, 83, 209217.

Gholamipoor S, Nikpour-Ghanavanti Y, Oromiehie AR \& Mohammadi M. 2013. Extraction and Characterization of Alginate from Sargassum angustifolium collected from northern coasts of Persian Gulf, Bushehr. International Symposium on Advances in Science and Technology, 1-5.

Gomez CG, Perez Lambrecht MV, Lozano JE \& Villar MA. 2009. Influence of the extraction-purification conditions on final properties of alginates obtained from brown algae (Macrocystis pyrifera). Int J Biol Macromol, 44(4):365-371.

Haerunnisa. 2008. Analisa Kualitas dan Formulasi Alginat Hasil Ekstraksi Sargassum filipendula Untuk Pembuatan Minuman Suplemen Serat Dalam Bentuk Effervescent. [Skripsi]. Program Studi Kimia Fakultas Sains dan Teknologi.

Hernandez-Carmona G, Freile-Pelegrin Y \& Hernandez-Garibay E. 2013. Conventional. In D. H., Functional ingredients from algae for foods and nutraceuticals (pp. 475-516). Cambridge: Woodhead Publishing Limited.

Hernandez-Carmona G, Mchugh DJ, Arvizu-Higuera DL \& RodriguezMontesions YE. 1999. Manual de tecnicas de control de calidad para el acido y sus derivados. Mexico: CICIMAR-IPN.La Paz. 
Indrani D and Budianto E. 2013. A study of extraction and characterization of alginates obtained from brown macroalgae Sargassum duplicatum and Sargassum crassifolium from Indonesia. Dental Journal Vol.2, 65-70. Jayasinghe PS, Pahalawattaarachchi V \& Ranaweera KKDS. 2016. Effect of Extraction Methods on the Yield and Physiochemical Properties of Polysaccharides Extracted from Seaweed Available in Sri Lanka. Poultry, Fisheries and Wild life Science, 1-6.

Kasim S, Marzuki A\& Sudir S. 2017. Effects of Sodium Carbonate Concentration and Temperature on the Yield and Quality Characteristics of Alginate Extracted from Sargassum sp. Research Journal of Pharmaceutical, Biological and Chemical Sciences, 8(1) 660-667.

Kraan S. 2012. In Carbohydrates-Comprehensive Studies on Glycobiology and Glycotechnology. In Algal Polysaccharides, Novel Applications and Outlook (pp. 518 (489-532). Accessed from INTECH open access chapter, Creative Commons Attribution Licensed.

Mariamo AL. 1977. Sulfated Seaweed Polysaccharide Food Colloids. AVI Wesport, Connecticut, 80-95.

Mazumder A, Holdt SL, De Francisci D, Alvarado-Morales M \& Mishra HN. 2014. Optimization of extraction process of crude alginate from Sargassum muticum by response surface methodology. Poster session presented at 5th Congress of the International Society for Applied Phycology. Sydney, Australia, Technical University of Denmark.

Mchugh DJ. 2003. A guide to seaweed industry. FAO fisheries technical paper no. 441. FAO Rome.

Mohamed F, Ahmed B, El Montassir D, Moha T \& Francois B. 2017. Extraction and characterization of sodium alginate from Moroccan Laminaria digitata brown seaweed. Arabian Journal of Chemistry, 1-8.

Mushollaeni W. 2007. Extraction of Alginate from Brown Seaweeds Sargassum, and Turbinaria. Young Lecturer Experiment Paper, 20-33.

Mushollaeni W. 2011. The physicochemical characteristics of Sodium Alginate from Indonesian brown seaweeds. African Journal of Food Science, Vol. 5 (6) 349-352.

Nalamothu N, Potluri A \& Mupalla M. 2014. Review on Marine Alginates and its Application. Indo American Journal of Pharmaceutical Research, 110.

Nijhuis A, Van Der Knaap HCM, Jond SDE \& Vandeginste BGM. 1999. Strategy for ruggedness tests in chromatographic method validation. Anal chim Acta, 391:187-202.

Ortiz AT and Trono GC. 2000. Growth and reproductive pattern of intertidal and subtidal Sargassum (Sargassaceae, Phaeophyta) populations in Bolinao, Pangasinan. Science Diliman, 12(2): 45-50.

Peteiro C. 2018. Alginate Production from Marine Macroalgae, with Emphasis on Kelp Farming. In B. \&. Rehm, Alginates and Their Biomedical Applications (pp. 1-41). Singapore: Springer Series in 


\section{Improving the Extraction Process of Sodium Alginate from Samu}

Biomaterials Science and Engineering 11.

Plackett RL and Burman JP. 1946. The design of optimum multifactorial experiments. Biometrika, 33:305-325.

Prince JS and O'neal SW. 1979. The ecology of Sargassum pteropleuron Grunow (Phaeophyceae, Fucales) in the waters of Sourth Florida: I. Growth, reproduction and population structure. Phycologia, 109-114.

Reyes-Tisnado R, Hernandez-Carmona G, Montesinos YE, Higuera DL \& Gutierrez FL. 2005. Food Grade Alginates Extracted from the Giant Kelp Macrocystis pyrifera at Pilot-Plant Scale. Rev. Invest Mar., 26(3): 185192.

Siala R, Frikha F \& Mhamdi S. 2012. Optimization of acid protease production by Aspergillus niger II on shrimp peptone using statistical experiment design. The Scientific World Journal, 1-11.

Swee-Yong C, Ping-Keong W \& Ching-Lee W. 2009. Extraction and characterization of alginate from brown seaweeds (Fucales, Phaeophyceae) collected from Port Dickson, Peninsular Malaysia. Journal of Applied Phycology, 23:191-196.

Truss V, Taure D \& Grasdalen H. 2001. Algal biomass from Fucus vesiculosus (Phaeophyta): Investigation of the Mineral and Alginate Components. Proc. Estonian Acad. Sci. Chem, 50: 95-103.

Vanaja K and Shobha Rani RH. 2008. Design of Experiments: Concept and Applications of Plackett Burman Design. Clinical Research and Regulatory Affairs, 24:1, 1-23.

Wass JA. 1997. Formal experimental design and analysis for immunochemical product development. Part I. IVD Technology Magazine.

Winarno F and G. Seaweed. 1990. Processing Technology. Pustaka Sinar Harapan, Jakarta.

Yani M. 1998. Modification and Optimation Processing of Alginate Extraction from Jenis Turbinaria sp. Final Paper. Agricultural Faculty of Bogor Agricultural Institute. Bogor, 20-35.

Yannis LL. 2001. A Plackett-Burman screening design directs the efficient formulation of multicomponent DRV liposomes. Journal Pharm Biomed Anal, 26: 255-263.

Yunizal J, Murtini T, Basmal J, Nasran S, Marsiana E \& Abdulrokim I. 1999. Technology of Extraction Alginate from Brown Seaweeds. Technical Paper, Jakarta, 25-40.

Zailanie K. 2015. Study of Alginate Sargassum Filipendula with FTIR Confirmation. Journal of Life Science and Biomedicine, 5(6): 167-170. 